International Research Journal of Management, IT \& Social Sciences
Available online at https://sloap.org/journals/index.php/irjmis/
Vol. 6 No. 4, July 2019, pages: 197 206
ISSN: 2395-7492
https://doi.org/10.21744/irjmis.v6n4.682

\title{
Effect of Role Overload, Budget Participation, Environmental Uncertainty, Organizational Culture, Competence, and Compensation on Employee Performance
}

\author{
Gusti Ayu Putu Eka Dewi Prihantari ${ }^{\text {a }}$ \\ Ida Bagus Putra Astika b
}

Article history:

Received: 09 March 2019

Accepted: 31 May 2019

Published: 31 July 2019

\section{Keywords:}

budgeting participation; environmental uncertainty; employee performance; organizational culture; role overload;

\begin{abstract}
The purpose of this study was to obtain empirical evidence of the effect of role overload, budgetary participation, environmental uncertainty, organizational culture, competence, and compensation on employee performance. The population in this study were all employees of PT. Tatamulia Nusantara Indah. The method of determining the sample used in this study is the saturated sample method. Saturated sample method is a sampling technique if all members of the population are used as samples so that the number of respondents in this study is 90 respondents. The data used in the form of primary data using a questionnaire. The analysis technique used is multiple linear regression. The results showed that role overload negatively affected employee performance, budgeting participation had a positive effect on employee performance, environmental uncertainty had a negative effect on employee performance, organizational culture had a positive effect on employee performance, competency had a positive effect on employee performance, and compensation had a positive effect on employee performance at PT. Tatamulia Nusantara Indah.
\end{abstract}

2395-7492@ Copyright 2019. The Author. This is an open-access article under the CC BY-SA license (https://creativecommons.org/licenses/by-sa/4.0/) All rights reserved.

\section{Author correspondence:}

Gusti Ayu Putu Eka Dewi Prihantari,

Faculty of Economics and Business Udayana University, Denpasar, Indonesia.

Email address: ekatata.acc@gmail.com

\section{Introduction}

Every company activity is closely related to the achievement of the company's direction in the future which is stated in the company's mission and vision. However, there is often a lack of clarity of expectations for the role it plays, or there is a conflict between expectations for one role and the other, uncertainty about the meaning of the performance being implemented, and the employee's lack of understanding of the expected performance. This will result in stress on employees. Stress is a condition in which employees are confronted with an opportunity, obstacle, or demand that

${ }^{\text {a }}$ Faculty of Economics and Business, Udayana University, Denpasar, Indonesia

${ }^{\mathrm{b}}$ Faculty of Economics and Business, Udayana University, Denpasar, Indonesia 
is associated with what is produced (Robbins, 2013). Job stress can be positive which is needed to produce high achievement, but generally, job stress is more detrimental to employees and companies (Munandar, 2008). The negative impact caused by work stress can be physiological, psychological and behavioral symptoms (Robbins, 2013). Stress exists in every organization whether large or small in the workplace and organization has become so complex because stress has a significant effect on employee job performance.

Role stress or stress is a condition in which a person has difficulty in understanding what is the task, the role that is felt too heavy or plays various roles in the place they work. Stress because the role is a situation where there are goals and emotions that are not in accordance with each other, in the self between individuals that cause conflict (Winardi, 2004). Mismatch of expertise with job specifications, the ambiguity of career paths and roles, lack of personnel, and limited time to complete work, can also cause pressures that lead to fatigue and stress experienced by employees. Job stress can lead to job dissatisfaction, high employee turnover, and decreased performance, which can ultimately damage the credibility of the employee itself. Fogarty et al., (2000), states that there are three types of role stress, namely role conflict (role conflict), role ambiguity (role ambiguity) and role overload (excess role).

Stress is needed to increase one's motivation or drive to improve performance. However, when stress increases to a high level, performance will decrease further because the person will use his energy to deal with stress rather than doing his job. In the inverted U image made by Robbins (2008), it describes the reaction to stress over time and there is a change in stress intensity. This means that the level is carrying a negative influence on long-term performance because the intensity of continuous stress decreases the performance of individuals in work, a high level will have a negative effect on long-term performance.

The increasingly tight competition in the business world requires companies to work effectively and efficiently in order to survive and develop better. The right strategic steps are needed by the company is facing competition. The company must be able to manage resources in order to provide satisfactory services so that they can achieve the planned goals and objectives. One important component in corporate planning is the budget. The budget is a plan for future activities. An organization needs a budget to translate the entire strategy into short-term and long-term plans and goals (Hansen \& Mowen, 1997; Chanana \& Gupta, 2016; Kawiana et al., 2018). Budget is an element of a management control system that functions as a planning and control tool so that managers can carry out organizational activities more effectively and efficiently (Schief \& Lewin, 1970). As a planning tool, the budget is an activity plan consisting of a number of targets that will be achieved by the department managers of a company in carrying out a series of certain activities in the future.

The budgeting process is basically a role setting process, where each employee in the company is given the role to carry out activities to achieve the targets set by the budget. So that the process in budgeting involves various levels of management, both top management (top-level management) to lower-level management (lower level management). The budget has a direct impact on human behavior, especially for people who are directly involved in the process of drafting or designing the budget (Siegel, 1989). Therefore participation in budget determination involving various levels of management is very necessary.

Budgeting participation is the involvement of budget implementers in the process of drafting a budget. Research conducted by Hartanti (2002), proves that participation can influence the rise and fall of a budgetary slack, this is characterized by positive communication by managers so that subordinates are not motivated to create budgetary slack. Effective budget requires managers who have the ability to predict the future by considering various factors, such as environmental factors (Yuwono, 1999; Kawiana et al., 2018; Pant \& Yadav, 2016). In anticipating an ever-changing situation so that the company can survive and develop, the company is also required to manage and maximize all available resources in the company, so that management requires all information, especially information related to budgeting tasks to achieve maximum performance.

Maximum performance can be achieved if the company's employees have competence in their fields. Competence possessed by an employee is the ability possessed to work in accordance with the desired goals of the organization. Competence can improve performance because with high competence it impacts on employee confidence in work. The competencies in question are education, experience, and training. Higher education causes an employee to be able to absorb the knowledge received, the longer occupying an employee position will make the experience in completing the task will be better, faster, more accurate. As well as the amount of training that an employee follows will increase his skills. These three indicators can be reflected in employee competencies that can provide motivation in work.

Employee performance is one of the important factors in the success of a company. One important policy needed in creating employee performance is the provision of compensation that is able to motivate employee performance. Fair and structured compensation can provide motivation for employees to create employee performance in accordance with what is expected by the company (Hasibuan, 2007). Thus the provision of appropriate compensation will have an 
impact on employee responsibilities in carrying out their duties and provide good results/achievements within the company itself.

Compensation is a broad term and relates to financial rewards received by employees in a company or organization (Luthans, 1998). Compensation is also monetary or non-monetary services that employees receive as a consequence or substitute for their work. Therefore, it can be concluded that compensation is anything (whether in the form of money or not money) that employees receive as a reward for their work. Compensation is divided into financial and non-financial compensation. Financial compensation in the form of salaries and incentives and payment of wages when not working. While non-financial compensation in the form of opportunities for promotion or promotion, health insurance or general protection, and facilities provided by companies such as vehicles or housing (Simamora, 2008). Both forms of compensation play an important role in employee performance. This is evidenced by the results of the study of Hadian \& Limbong (2012), which states that appropriate compensation will increase employee performance motivation. With the increase in work motivation, it is expected to improve employee work performance.

Other resources needed by a company are organizational culture. Organizational culture is defined as a cognitive framework that contains the attitudes, values, norms, and shared expectations held by members of the organization (Greenberg \& Baron, 2003; Pratiwi et al., 2019; Romario et al., 2019). Organizational culture is also defined as a pattern or basic assumption shared by a group when solving problems of external adaptation and internal integration, which have succeeded and are considered legitimate to be taught to new members as an appropriate way of accepting, thinking, and feeling related to this (Schein, 1985; Sukayana \& Putri, 2019; Widiani et al., 2019).

Organizational culture functions as an adhesive, unifying, identity, image, motivator for all employees and the people in it. Furthermore, the value system is inherited to the next generation and can be used as a reference for human behavior in organizations that are oriented towards achieving goals or set performance results. Productive culture is a culture that can make an organization strong and corporate goals can be realized. Organizational culture plays an effective role in an organization to increase individual responsibility in the organization. A strong culture will have a large influence on the behavior of its members because of the high level of togetherness and intensity creating an internal climate of high behavioral control (Robbins \& Judge, 2002). Culture is the root of the tradition, so culture reflects what is done, and not what will apply (in Moeljono, 2005).

One of the effects of organizational culture is organizational performance. Companies with a culture that attach importance to customers, shareholders and employees perform better than companies that do not have these characteristics (Kotter \& Hesket, 1997). Strong organizational culture produces better short-term performance (Gordon \& Tomaso, 1992). Robbins (2004), in one study of organizational culture, suggests that employees in companies whose culture is stronger are more committed to their company than employees in companies whose culture is weak. Firms with a strong culture will also use their recruitment efforts and socialization practices to foster employee commitment.

\section{Literature Review and Hypothesis}

The concept of this study illustrates the influence of role overload, budgeting participation, environmental uncertainty, organizational culture, competence, and compensation on employee performance. Inaccuracies in measuring employee performance can be caused by many factors, including the lack of clarity of expectations for the role they play, or there is a conflict between expectations for one role with another, uncertainty about the meaning of the performance being implemented, and employee lack of understanding of expected performance. This also causes role overload because of the role that will influence the effectiveness of the company.

The budgeting process is basically a role setting process where each manager within the organization is given the role to carry out activities to achieve the goals set by the budget. The process in budgeting involves various levels of management. The budget has a direct impact on human behavior, especially for employees who are directly involved in the budgeting/drafting process (Siegel, 1989). Effective budget requires employees who have the ability to predict the future by considering various factors, such as environmental factors. Organizational culture plays an effective role in an organization to increase individual responsibility in the organization. One of the effects of organizational culture is employee performance.

Maximum performance can be achieved if the company's employees have competence in their fields. Competence possessed by an employee is the ability possessed to work in accordance with the desired goals of the organization. One important policy needed in creating employee performance is the provision of compensation that is able to motivate employee performance. Providing appropriate compensation will have an impact on employee responsibilities in carrying out their duties, and provide good results/achievements within the company itself. Based on the explanation above, the concept of this research can be presented in Figure 1 below.

Prihantari, G. A. P. E. D., \& Astika, I. B. P. (2019). Effect of role overload, budget participation, environmental uncertainty, organizational culture, competence, and compensation on employee performance. International

Research Journal of Management, IT and Social Sciences, 6(4), 197-206. https://doi.org/10.21744/irjmis.v6n4.682 


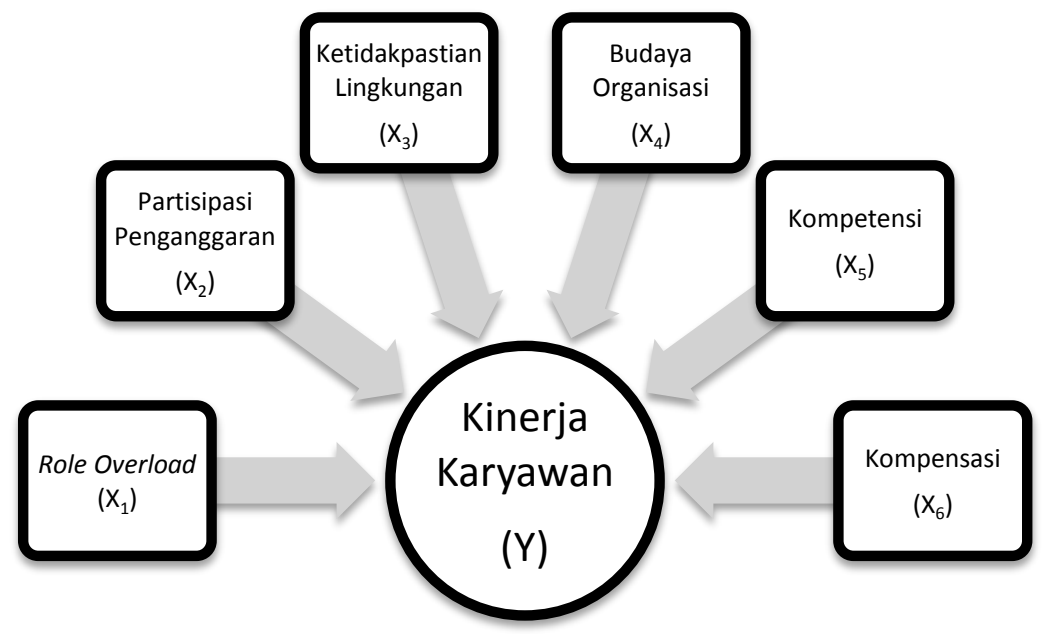

Figure 1. Conceptual framework

\section{Hypothesis}

H1: role overload negatively affects employee performance

$\mathrm{H} 2$ : budgetary participation has a positive effect on employee performance

$\mathrm{H} 3$ : environmental uncertainty has a negative effect on employee performance.

H4: organizational culture has a positive effect on employee performance

H5: competence has a positive effect on employee performance

H6: compensation has a positive effect on employee performance

\section{Materials and Methods}

This research was conducted at PT. Tatamulia Nusantara Indah, Bali branch. This location was chosen because the researchers found a phenomenon of unclear role faced by employees that affects the performance of employees themselves, how employees face uncertainties in the company's environment amid tender negotiations, the influence of organizational culture that can affect employee performance, employee competencies that can advance the company, and compensation at the company.

The population is employees of PT. Tatamulia Nusantara Indah. The method of determining the sample used in this study is the saturated sample method. Saturated sample method is a sampling technique if all members of the population are used as samples so that the number of respondents in this study is 90 respondents.

Data were analyzed using multiple regression analysis, to obtain empirical evidence of the effect of role overload, budgeting participation, environmental uncertainty, organizational culture, competence, and compensation for employee performance used multiple linear regression analysis techniques. Multiple linear analysis is used to solve the existing problem formulation, namely to see the effect of between two or more variables.

\section{Results and Discussions}

\section{Multiple Linear Regression Test}

Testing the hypothesis by using multiple linear regression tests The test results can be seen in Table 1, namely as follows: 
Table 1.

The Effects of Role Overload, Budgeting Participation, Environmental Uncertainty, Organizational Culture, Competence, Compensation on Performance

\begin{tabular}{|c|c|c|c|c|c|c|}
\hline \multicolumn{2}{|c|}{ Model } & \multicolumn{2}{|c|}{$\begin{array}{l}\text { Unstandardized } \\
\text { Coefficients }\end{array}$} & $\begin{array}{c}\text { Standardized } \\
\text { Coefficients }\end{array}$ & \multirow[t]{2}{*}{$\mathrm{t}$} & \multirow[t]{2}{*}{ Sig. } \\
\hline & & $\mathrm{B}$ & Std. Error & Beta & & \\
\hline \multirow{7}{*}{1} & (Constant) & 10.850 & 1.739 & & 6.238 & .000 \\
\hline & $\mathrm{X} 1$ & -.126 & .042 & -.135 & -2.969 & .004 \\
\hline & $\mathrm{X} 2$ & .226 & .072 & .319 & 3.149 & .002 \\
\hline & X3 & -.048 & .024 & -.093 & -2.028 & .046 \\
\hline & $\mathrm{X} 4$ & .146 & .029 & .246 & 5.081 & .000 \\
\hline & $\mathrm{X} 5$ & .220 & .024 & .442 & 9.042 & .000 \\
\hline & X6 & .196 & .066 & .298 & 2.952 & .004 \\
\hline
\end{tabular}

Primary Data, 2019

Based on Table 1, a regression equation model can be made, as follows:

$$
Y=10,850-0,126 X_{1}+0,226 X_{2}-0,048 X_{3}+0,146 X_{4}+0,220 X_{5}+0,196 X_{6}
$$

\section{Determination Coefficient Test $\left(R^{2}\right)$}

The coefficient of determination test is conducted to find out how far the ability of the independent variable (independent) to explain the dependent variable (dependent), this can be seen from the value of $\mathrm{R}^{2}$, namely adjusted $\mathrm{R}^{2}$.

Table 2

$\mathrm{R}^{2}$

\begin{tabular}{|c|c|c|c|c|}
\hline Model & $\mathrm{R}$ & R Square & Adjusted R Square & Std. Error of the Estimate \\
\hline 1 & $.926^{\mathrm{a}}$ & .858 & .846 & .94893 \\
\hline
\end{tabular}

Primary Data, 2019

Based on Table 2 the adjusted R2 value of 0.951 , this means that 95.1 percent of role overload variables, budget participation, environmental insecurity, organizational culture, competence, and compensation affect employee performance while the remaining 4.9 percent is influenced by other variables not included in the research.

\section{The Effect of Role Overload on Employee Performance}

Based on the results of the study indicate that role overload negatively affects employee performance. This result answers hypothesis 1 which states that role overload negatively affects employee performance. This means that the higher the role overload, the lower the employee's performance. The role played by someone can be a factor in overload because someone in his life does not only play one role. Stress can occur if individuals have difficulty interpreting the expectations of others, there are conflicts between expectations for one role and the other (Hutami \& Chariri, 2011). Role conflict creates discomfort in work and can reduce work motivation because it has a negative impact on individual behavior, such as the emergence of work tension, the amount of displacement, decrease in job satisfaction so that it can reduce the auditor's overall performance (Fanani et al., 2008). Research by Fisher (2001); Viator (2001); Fanani et al., (2007); Agustina (2009); Widyastuti \& Sumiati (2011), state that role conflict influences performance.

\section{The Effect of Budgeting Participation on Employee Performance}

Based on the results of the study indicate that budget participation has a positive effect on employee performance. This result answers hypothesis 2 which states that budgetary participation has a positive effect on employee performance. This means that the higher the budgeting participation, the higher the employee's performance. The biggest contribution of budgeting activities is the participation of managers and subordinates because they have to

Prihantari, G. A. P. E. D., \& Astika, I. B. P. (2019). Effect of role overload, budget participation, environmental uncertainty, organizational culture, competence, and compensation on employee performance. International

Research Journal of Management, IT and Social Sciences, 6(4), 197-206. https://doi.org/10.21744/irjmis.v6n4.682 
realize the budget and their performance, especially managers are measured based on the success in realizing the budget. Previous research such as Nor (2007) and Milani (1975), showed that budgetary participation with employee performance has a significant positive relationship. High budgeting participation results in high employee performance. Conversely, low budgeting participation results in low employee performance. Research conducted by Bass \& Leavit (1963); Schulec \& Kim (1976); Brownell \& Mc Innes (1986); and Indriantoro (1993), found that there was a positive and significant relationship between budgetary participation and managerial performance.

\section{The Effect of Environmental Uncertainty on Employee Performance}

Based on the results of the study indicate that uncertainty has a negative effect on employee performance. This result answers hypothesis 3 which states that environmental uncertainty has a negative effect on employee performance. This means that the higher the environmental uncertainty, the lower the employee's performance. Environmental uncertainty is a condition where an individual is unable to predict something accurately. High environmental uncertainties influence the greater employee performance. Gul \& Chia (1994), research shows that performance will increase in high environmental uncertainties because employees will try to find enough information for the interests of the company.

\section{The Effect of Organizational Culture on Employee Performance}

Based on the results of the study show that organizational culture has a positive effect on employee performance. These results answer hypothesis 4 which states that organizational culture has a positive effect on employee performance. This means that the higher the organizational culture, the higher the employee's performance. The strength of the organizational culture is determined by dimensions, intensity, crystallization, homogeneity, and stability. A strong organizational culture will help organizations provide certainty for their members who develop with the organization. Susanto (1997) explained that a weak culture would not be able to provide encouragement for employees to have a developed desire with the organization. Gordon and Tomaso (1992) developed research on organizational culture and the results of his research support the findings of Denison (1990), that a strong organizational culture produces better short-term performance.

\section{The Effect of Competence on Employee Performance}

Based on the results of the study indicate that competence has a positive effect on employee performance. This result answers hypothesis 5, which states that the competence has a positive effect on employee performance. This means that the higher the competence, the higher the employee's performance. Mardiasmo (2005), states that performance (performance) is a description of the level of achievement of an activity/program/ policy in realizing the goal, that competence does not have a significant effect on employee performance. Likewise with Linawati \& Suhaji's research (2011) which states that the competency variable does not have a significant effect on employee performance at PT. Herculon Carpet Semarang. The results of the research by Dyah Kusumastusi (2001), show that individual competence has a positive and significant effect on performance with a contribution of influence of 0.728 . Bambang Suprapto's (2006), research shows that empowerment and competence together or partially influence performance

\section{The Effects of Compensation on Employee Performance}

Based on the results of the study indicate that compensation has a positive effect on employee performance. This result answers hypothesis 6 which states that compensation has a positive effect on employee performance. This means that the higher the compensation, the higher the employee's performance. Prawiro's (1999), research shows that employee performance will be good if paid or given wages in accordance with the agreement. Kuswinarno's (2013) research, Supiyanto (2015), and Handoko (2010), also showed a significant positive effect between financial and nonfinancial compensation both simultaneously and partially on employee performance. It is different from the research of Idris (2015) and Murty (2012), which proves that compensation does not have a significant effect on employee performance, because financial compensation is not the only factor that influences employee performance, and the amount of compensation given by the company is still felt unfair and not as expected employee. The results of the Yuki \& Latham (1975), the study also show that wage or salary incentives do not provide consistent results on employee performance. 


\section{Conclusion}

a) Role overload negatively affects employee performance at PT. Tatamulia Nusantara Indah, this means that the higher role overload, the lower the employee's performance.

b) Budgeting participation has a positive effect on employee performance at PT. Tatamulia Nusantara Indah, this means that the lower the budgeting participation, the lower the employee's performance.

c) Environmental uncertainty has a negative effect on employee performance at PT. Tatamulia Nusantara Indah, this means that the higher the environmental uncertainty, the lower the employee's performance.

d) Organizational culture has a positive effect on employee performance at PT. Tatamulia Nusantara Indah, this means that the higher the organizational culture, the higher the employee's performance.

e) Competence has a positive effect on the performance of employees at PT. Tatamulia Nusantara Indah, this means that the higher the competence, the higher the employee's performance.

f) Compensation has a positive effect on the performance of employees at PT. Tatamulia Nusantara Indah, this means that the higher the compensation, the higher the employee's performance.

\section{Suggestion}

a) The next researcher is suggested to be able to develop in this research by researching in companies with different branches to be used as material for comparison and adding other variables that support the company is preparing new policies.

b) Further research is recommended to add variables originating from internal factors, such as motivation, education, and others, to find out more about employee performance.

c) Companies are advised to focus more on the division of tasks of each department so that there is no excess role when an employee has too much work to do under the pressure of a very tight schedule and unclear assignments and results of employee performance that can affect the company.

d) Companies should be able to appreciate employees through moral support and open attitudes, and awards outside of giving salary or bonuses to work results so that social support can be formed that can improve employee performance.

e) Companies need to schedule questionnaires or questionnaires regarding work stress on a regular basis so that it can be used as a benchmark for the company performance.

\section{Conflict of interest statement and funding sources}

The authors declared that they have no competing interest.

Statement of authorship

The authors have a responsibility for the conception and design of the study. The authors have approved the final article.

\section{Acknowledgments}

The authors would like to thank the Editor of IRJMIS for their valuable time, support, and advice in completing the current study.

Prihantari, G. A. P. E. D., \& Astika, I. B. P. (2019). Effect of role overload, budget participation, environmental uncertainty, organizational culture, competence, and compensation on employee performance. International Research Journal of Management, IT and Social Sciences, 6(4), 197-206. https://doi.org/10.21744/irjmis.v6n4.682 


\section{References}

Agustina, L. (2011). Pengaruh Konflik Peran, Ketidakjelasan Peran, dan Kelebihan Peran terhadap Kepuasan Kerja dan Kinerja Auditor (Penelitian pada Kantor Akuntan Publik yang Bermitra Dengan Kantor Akuntan Publik Big Four di Wilayah DKI Jakarta). Jurnal Akuntansi Maranatha, 1(1), 40-69.

Bass, B. M., \& Leavitt, H. J. (1963). Some experiments in planning and operating. Management Science, 9(4), 574585.

Brownell, P., \& McInnes, M. (1986). Budgetary participation, motivation, and managerial performance. Accounting review, 587-600.

Chanana, M., \& Gupta, K. (2016). Quality of work life and its impact on job performance: a study of S.B.I \& HDFC banking professionals. International Research Journal of Management, IT and Social Sciences, 3(5), 16-24.

Denison, D. R. (1990). Corporate culture and organizational effectiveness. John Wiley \& Sons.

Djokosantoso, M. (2005). Budaya Organisasi dalam Tantangan. Jakarta: PT. Elex Media Komputindo.

Fanani, A. Z. (2007). Bermain Logika Action Script Macromedia Flash Prod 8. Elex Media Komputindo.

Fanani, Z., Hanif, R. A., \& Subroto, B. (2008). Pengaruh struktur audit, konflik peran, dan ketidakjelasan peran terhadap kinerja auditor. Jurnal Akuntansi dan Keuangan Indonesia, 5(2), 139-155.

Fisher, A. S., \& Kaplan, S. J. (2001). U.S. Patent No. 6,243,691. Washington, DC: U.S. Patent and Trademark Office.

Fisher, C. (1996). The impact of perceived environmental uncertainty and individual differences on management information requirements: A research note. Accounting, Organizations and Society, 21(4), 361-369. https://doi.org/10.1016/0361-3682(95)00029-1

Fogarty, T. J., Singh, J., Rhoads, G. K., \& Moore, R. K. (2000). Antecedents and consequences of burnout in accounting: Beyond the role stress model. Behavioral Research in Accounting, 12, 31-68.

Gordon, G. G., \& DiTomaso, N. (1992). Predicting corporate performance from organizational culture. Journal of management studies, 29(6), 783-798. https://doi.org/10.1111/j.1467-6486.1992.tb00689.x

Greenberg, J., \& Baron, R. A. (1995). Behavior in organizations: understanding and managing the human side of work. Englewood Cliffs, NJ: Prentice Hall.

Gul, F. A., \& Chia, Y. M. (1994). The effects of management accounting systems, perceived environmental uncertainty and decentralization on managerial performance: a test of three-way interaction. Accounting, Organizations and Society, 19(4-5), 413-426. https://doi.org/10.1016/0361-3682(94)90005-1

Handoko, Y. (2010). Effect On Value Of Financial Performance Company With Corporate Social Responsibility Disclosures And As A Good Corporate Governance Moderating Variable. Jurnal. Undergraduate Program, Faculty of Economics Gunadarma University.

Hansen, D. R. Maryanne M. mowen. 1997. Management Accounting. Cincinnati Ohio. South Western Publishing Co.

Hartanti, N. (2002). Post Power Syndrome sebagai Gangguan Mental pada Masa Pensiun. Tazkia Jurnal Psikologi Berbasis Keilmuan.

Hasibuan, M. S. (2010). Manajemen sumber daya manusia. Bumi Aksara.

Hutami, G., \& Chariri, A. (2011). Pengaruh Konflik Peran dan Ambiguitas Peran Terhadap Komitmen Independensi Auditor Internal Pemerintah Daerah (Studi Empiris pada Inspektorat Kota Semarang) (Doctoral dissertation, Universitas Diponegoro).

Idris, A. H., Guffey, D., Pepe, P. E., Brown, S. P., Brooks, S. C., Callaway, C. W., ... \& Kudenchuk, P. J. (2015). Chest compression rates and survival following out-of-hospital cardiac arrest. Critical care medicine, 43(4), 840-848.

Indriantoro, N. (1994). The effect of participative budgeting on job performance and job satisfaction with locus of control and cultural dimensions as moderating variables.

Kawiana, I. G. P., Dewi, L. K. C., Martini, L. K. B., \& Suardana, I. B. R. (2018). The influence of organizational culture, employee satisfaction, personality, and organizational commitment towards employee performance. International Research Journal of Management, IT and Social Sciences, 5(3), 35-45.

Kawiana, I. G. P., Dewi, L. K. C., Martini, L. K. B., \& Suardana, I. B. R. (2018). The influence of organizational culture, employee satisfaction, personality, and organizational commitment towards employee performance. International Research Journal of Management, IT and Social Sciences, 5(3), 35-45.

Kim, H. M., Lyons, K., \& Cunningham, M. A. (2008, January). Towards a framework for evaluating immersive business models: Evaluating service innovations in second life. In Proceedings of the 41st Annual Hawaii International Conference on System Sciences (HICSS 2008) (pp. 110-110). IEEE.

Kotter, J. P., \& Heskett, J. L. (1997). Dampak Budaya Perusahaan Terhadap Kinerja. Jakarta: Prenhallindo.

Kusumastuti, D. (2001). Manajemen Sistem pengembangan Sumber Daya Dosen Sebagai Penjamin Mutu di Perguruan Tinggi. Disertasi. UPI. 
Kuswinarno, M. (2016). Pengaruh Pengembangan Sumber Daya Manusia Dalam Meningkatkan Produktivitas Karyawan PT. BRI (PERSERO), TBK Cab. Bangkalan. Jurnal Studi Manajemen dan Bisnis, 1(1), 43-52.

Linawati, L., \& Suhaji, S. (2011). Pengaruh Motivasi, Kompetensi, Kepemimpinan, dan Lingkungan Kerja terhadap Kinerja Karyawan (Studi pada PT. Herculon Carpet Semarang). Jurnal Kajian Akuntansi dan Bisnis, 1(1).

Luthans, F. (1998). Organizational Behavior. Eight Edition.

Mardiasmo, D., Tywoniak, S., Brown, K. A., \& Burgess, J. (2008). Asset management and governance: Analysing vehicle fleets in asset-intensive organisations.

Milani, K. (1975). The relationship of participation in budget-setting to industrial supervisor performance and attitudes: a field study. The accounting review, 50(2), 274-284.

Munandar, A. S. (2001). Psikologi industri dan organisasi. Universitas Indonesia (UI-Press).

Murty, W. A\& Hudiwinarsih, G. 2012. Pengaruh Kompensasi, Motivasi terhadap Komitmen Organisasional Karyawan. The Indonesian Accounting Review, 2(2), 215-228.

Nor, W. (2007). Desentralisasi dan Gaya Kepemimpinan Sebagai Variabel Moderating Dalam Hubungan Partisipasi Anggaran dan Kinerja Manajerial. Simposium Nasional Akuntasi.

Pant, I., \& Yadav, R. K. (2016). Impact of emotional intelligence on the job performance of employee. International Research Journal of Management, IT and Social Sciences, 3(1), 7-14.

Pratiwi, I. Y., Ratnadi, N. M. D., Suprasto, H. B., \& Sujana, I. K. (2019). The effect of role conflict, role ambiguity, and role overload in burnout government internal supervisors with tri hita karana culture as moderation. International Research Journal of Management, IT and Social Sciences, 6(3), 61-69. https://doi.org/10.21744/irjmis.v6n3.630

Prawiro, S. (1999). Manajemen Sumber Daya Manusia: Kebijakan Kinerja Karyawan. Edisi Pertama. Yogyakarta. BPFE.

Prawiro, S. (1999). Manajemen Sumber Daya Manusia: Kebijakan Kinerja Karyawan. Edisi Pertama. Yogyakarta. BPFE.

Robbins, J. (2004). The globalization of Pentecostal and charismatic Christianity. Annu. Rev. Anthropol., 33, 117-143.

Robbins, M., Judge, A., Liang, L., McClintock, K., Yaworski, E., \& MacLachlan, I. (2007). 2'-O-methyl-modified RNAs act as TLR7 antagonists. Molecular Therapy, 15(9), 1663-1669.

Robbins, P., \& Aydede, M. (Eds.). (2008). The Cambridge handbook of situated cognition. Cambridge University Press.

Robbins, S. P. (1996). Perilaku organisasi: Konsep, kontroversi, aplikasi. Jakarta: Prenhallindo.

Robbins, S. P. (2002). Prinsip-prinsip perilaku organisasi. Jakarta: Erlangga.

Robbins, S. P., \& Judge, T. (1992). Essentials of organizational behavior (Vol. 200, No. 1). Prentice Hall.

Robbins, S. P., \& Judge, T. A. (2013). Organizational Behavior (wydanie 15).

Romario, F. D., Putri, I. G. A. M. A. D., Badera, I. D. N., \& Putra, I. N. W. A. (2019). Effect of budget participation towards regional government managerial performance. International Research Journal of Management, IT and Social Sciences, 6(3), 101-107. https://doi.org/10.21744/irjmis.v6n3.638

Schein, E. H. (1990). Organizational culture (Vol. 45, No. 2, p. 109). American Psychological Association.

Schiff, M., \& Winters, L. A. (2003). Regional integration and development. The World Bank.

Siegel, G., \& Marconi, H. R. (1989). Behavioral Accounting South-Western Publishing Co. Cincinati.

Simamora, H. (2004). Manajemen sumber daya manusia.

Suhaji, L. (2010). Pengaruh Motivasi, Kompetensi, Kepemimpinan, dan Lingkungan Kerja terhadap Kinerja Karyawan: Studi pada PT Herculon Carpet Semarang. Skripsi Sarjana Tidak Diterbitkan. Semarang: STIE [Sekolah Tinggi Ilmu Ekonomi] Widya Manggala, Semarang.

Sukayana, G. A., \& Putri, I. A. D. (2019). Tri hita karana culture and organizational commitments moderate: effect of participation on budgetary slack. International Research Journal of Management, IT and Social Sciences, 6(4), 180-188. https://doi.org/10.21744/irjmis.v6n4.676

Supiyanto, Y. (2015). Pengaruh kompensasi, kompetensi dan komitmen organisasional terhadap kepuasan dan kinerja. Jurnal Economia, 11(2), 118-131.

Suprapto, T., \& Tommy, D. (2006). Pengantar Teori Komunikasi.

Susanto, A. B. (1997). Budaya Perusahaan: Seri Manajemen Dan Persaingan Bisnis. Cetakan Pertama, Elex Media Komputindo, Jakarta.

Viator, R. E. (2001). The association of formal and informal public accounting mentoring with role stress and related job outcomes. Accounting, Organizations and Society, 26(1), 73-93. https://doi.org/10.1016/S03613682(00)00002-7

Prihantari, G. A. P. E. D., \& Astika, I. B. P. (2019). Effect of role overload, budget participation, environmental uncertainty, organizational culture, competence, and compensation on employee performance. International Research Journal of Management, IT and Social Sciences, 6(4), 197-206. https://doi.org/10.21744/irjmis.v6n4.682 
Widiani, N. P., Putri, A. M. A. D., Sari, M. M. R., \& Wirajaya, I. G. A. (2019). The effect of love of money and emotional intelligence on employee performance with organizational citizenship behavior as mediating variable. International Research Journal of Engineering, IT \& Scientific Research, 5(1), 39-49. https://doi.org/10.21744/irjeis.v5n1.596

Widyastuti, T., \& Sumiati, E. (2011). Influence of Role Conflict, Role Ambiguity and Role Overload toward Auditors Performance. Dalam Jurnal Akuntabilitas, 10(2).

Winardi, R. D., Nugroho, W. S., \& Wijayanti, A. (2017). Long Tenure and Punishment Effect on Corrupt Behaviour. In SHS Web of Conferences (Vol. 34, p. 10003). EDP Sciences.

Yuki, N., \& Hartung, H. P. (2012). Guillain-Barré syndrome. New England Journal of Medicine, 366(24), 2294-2304.

Yuwono, B., \& Lee, D. L. (1997). Server ranking for distributed text retrieval systems on the internet. In Database Systems For Advanced Applications' 97 (pp. 41-49). 